\title{
A Survey of the Online Learning Implementation During COVID-19 Outbreak
}

\author{
https://doi.org/10.3991/ijes.v8i4.17913 \\ Handrie Noprisson \\ Universitas Mercu Buana, Jakarta, Indonesia \\ handrie.noprisson@mercubuana.ac.id
}

\begin{abstract}
This paper aim is to conduct a literature review of online learning implementation due to the impact of the COVID-19 outbreak. Specifically, the discussion will focus on the conditions of people, the facilities and technology used, and the process to support the success of online learning. The methodology of research adapted from systematic literature review method, namely PRISMA. As the result, we found as many 21 related works that explained people, technology and process aspect to implement online learning systems successfully. The main issues of online learning during COVID-19 is the availability of hardware (computer, phone, and so forth), software (Google Apps, Moodle, and so on) and internet connection. The list of tools recommendation for supporting activities of online learning is also discussed in this research.
\end{abstract}

Keywords - Case study, systematic review, online learning, COVID-19

\section{Introduction}

The spread of novel coronavirus disease or COVID-19 began at the end of 2019 in one of the states in China. This incident not only had an impact on sectors of life in China, but also people around the world. The rapid spread of the virus has resulted in decreased activity in the economic sector and increased use of facilities in the health sector [1]-[3].

When the COVID-19 outbreak began, several countries immediately implemented physical distancing regulations. As for areas with a high number of COVID-19 patients, the government has imposed a lockdown regulation so that the activities of all sectors of life are disrupted [1], [4]. After the declaration that the spread of COVID 19 was a 'pandemic', the government undertakes various prevention of the spread of disease, including lockdowns, restrictions on face-to-face learning, restrictions on long-distance travel and so on [5]-[7].

In the education sector, most governments have instructed schools to switch from face-to-face learning to fully online learning. All learning activities (discussions, training, exams, etc.) and learning support tools (books and other facilities) must be in digital form so that students can be accessed via the internet network [7]-[12]. Based on this situation, the research of online learning implementation is urgently needed. 
In this research, we will discuss case studies from various countries regarding online learning systems due to the impact of the COVID-19 outbreak. Specifically, the discussion will focus on the conditions of people, the facilities and technology used, and the process to support the success of online learning.

\section{Research Methodology}

In this research, we adapted the PRISMA method to conduct a systematic review. Information about the research stage to find related studies to answer the research question can be seen in Figure 1.

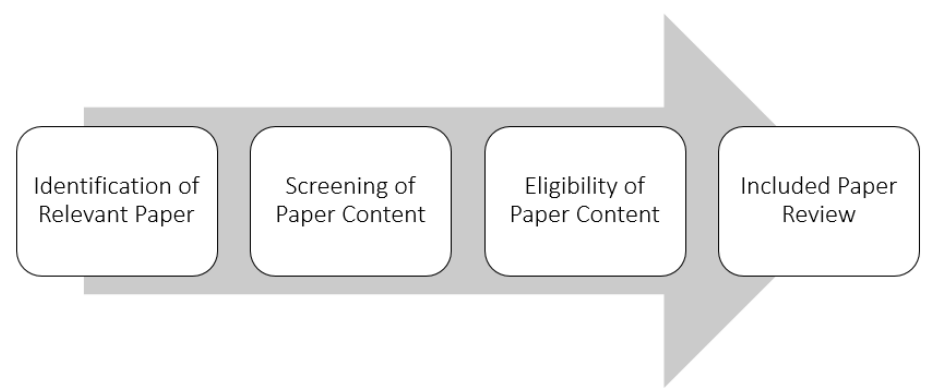

Fig. 1. Research phase adapted from PRISMA method [13]

We used several keywords to identify relevant research paper, including "online learning covid19", “online education covid19", "e-learning covid19", "education covid19". We search the paper in research databases such as PubMed, ProQuest, Science Direct, Google Scholar, IEEE Xplore and Wiley Online Library.

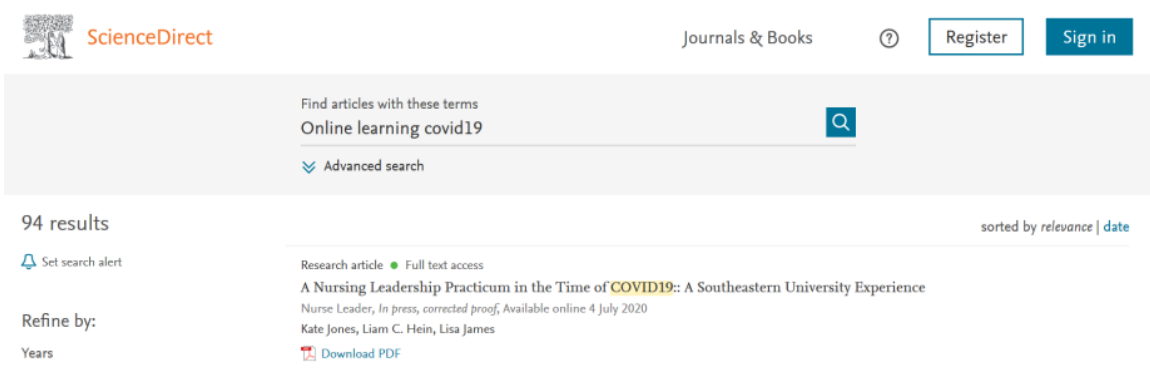

Fig. 2. Relevant research paper identification

All research related to the implementation of online learning during the COVID-19 outbreak fulfils the requirements for review with the criteria (i) publication date between 2019 and 2020, (ii) written in English, (iii) published in a reputable international journal, and (v) describes aspects of people or process or technology related to online learning during the COVID-19 pandemic. 
As guidance to conduct a systematic literature review, we defined three research questions in this study. The research question of this research is elaborated below:

- RQ1: What are the issues of people, process and technology due to online learning implementation during COVID-19 pandemic?

- RQ2: What are recommendation tools for online learning during COVID-19 outbreak?

\section{$3 \quad$ Result}

In this section, we delivered research result into three sub-sections, including data collection, online learning implementation and recommendation of tools for online learning.

\subsection{Data collection}

We found 21 works of literatures related to this research aims that is distributed by topic, type, country and object as can be seen in Table 1. Based on data distribution by country or location, one study was from China [14], one study was from Georgia [15], one study was from India [7], one study was from Indonesia [16], two studies were from Italy [1], [17], one study was from Jordan [18], two studies were from Philippines [6], [19], one study was from Spain [5], three studies were from Zambia [20]-[22] and other eight studies don't mention the location of research [23]-[30].

Table 1. Final data of relevant literature for this research $(n=21)$

\begin{tabular}{|l|l|l|l|l|c|}
\hline \multicolumn{1}{|c|}{ Author } & \multicolumn{1}{|c|}{ Topic } & \multicolumn{1}{|c|}{ Type } & \multicolumn{1}{c|}{ Country } & \multicolumn{1}{c|}{ Object } & Ref. \\
\hline (Dickinson and Gronseth 2020) & $\begin{array}{l}\text { People, Process, } \\
\text { Technology }\end{array}$ & Review & General & $\begin{array}{l}\text { Surgical } \\
\text { education }\end{array}$ & {$[23]$} \\
\hline (Haider and Al-Salman 2020) & People & Case Study & Jordan & Universities & {$[18]$} \\
\hline (Toquero 2020) & Process & Review & Philippines & Universities & {$[19]$} \\
\hline (Basilaia and Kvavadze 2020) & $\begin{array}{l}\text { People, Process, } \\
\text { Technology }\end{array}$ & Case Study & Georgia & School & {$[15]$} \\
\hline (Kapasia et al. 2020) & $\begin{array}{l}\text { People, Process, } \\
\text { Technology }\end{array}$ & Case Study & India & Universities & {$[7]$} \\
\hline (Favale et al. 2020) & Technology & Case Study & Italy & Universities & {$[1]$} \\
\hline (Pelmin 2020) & People & Review & Philippines & Universities & {$[6]$} \\
\hline (Mulenga and Marbán 2020b) & People & Case Study & Zambia & School & {$[21]$} \\
\hline (Sintema 2020) & People & Case Study & Spain & University & {$[5]$} \\
\hline (Gonzalez et al. 2020) & People & Review & General & University & {$[24]$} \\
\hline (Strielkowski 2020) & People & Review & General & $\begin{array}{l}\text { Medical } \\
\text { education }\end{array}$ & {$[25]$} \\
\hline $\begin{array}{l}\text { (Ahmed, Allaf, and } \\
\text { Elghazaly 2020) }\end{array}$ & Process & Review & General & $\begin{array}{l}\text { Medical } \\
\text { education }\end{array}$ & {$[26]$} \\
\hline (Rose 2020) & Process & Review & General & $\begin{array}{l}\text { Medical } \\
\text { education }\end{array}$ & {$[27]$} \\
\hline (Chick et al. 2020) & Process & Sambia & School & {$[22]$} \\
\hline
\end{tabular}




\begin{tabular}{|l|l|l|l|l|l|}
\hline (Kogan et al. 2020) & Process, Technology & Review & General & $\begin{array}{l}\text { Orthopaedic } \\
\text { education }\end{array}$ & {$[28]$} \\
\hline (Iyer, Aziz, and Ojcius 2020) & Process & Review & General & $\begin{array}{l}\text { Dental } \\
\text { education }\end{array}$ & {$[29]$} \\
\hline (Bao 2020) & Process & Review & China & University & {$[14]$} \\
\hline (Gallo and Trompetto 2020) & Process & Review & Italy & $\begin{array}{l}\text { Medical } \\
\text { education }\end{array}$ & {$[17]$} \\
\hline (Sandars et al. 2020) & Process & Review & General & University & {$[30]$} \\
\hline (Mailizar et al. 2020) & People & Case Study & Indonesia & School & {$[16]$} \\
\hline (Mulenga and Marbán 2020a) & People & Case Study & Zambia & School & {$[20]$} \\
\hline
\end{tabular}

\subsection{Online learning implementation}

There are many viewpoints of online learning implementation regarding issues of people, process and technology. This research succeeded in identifying studies related to online learning carried out during the COVID-19 outbreak. The statistic of a related study that is mapped to people, process and technology can be seen in Figure 3 below.

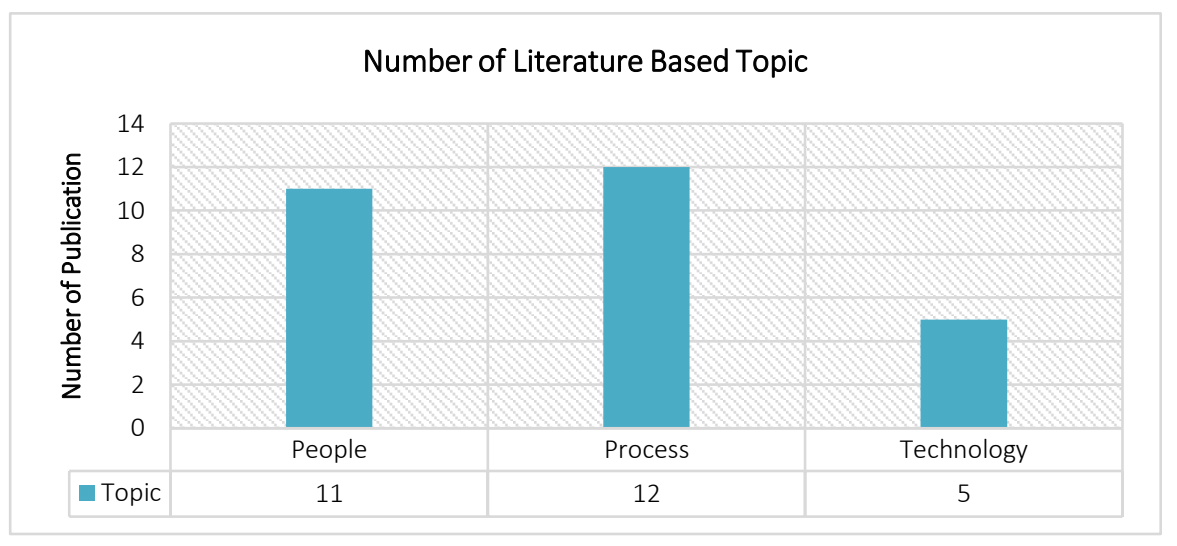

Fig. 3. Number of Literature Based Topic

To answer the research question (RQ1), "what is the issues of people, process and technology due to online learning implementation during COVID-19 pandemic?", we presented of viewpoints of online learning implementation in two countries, Georgia and India. We selected the country because the research paper elaborated the complete activities of online learning with the case study. Moreover, the distribution of research paper based on the country can be seen in Figure 4 below. 


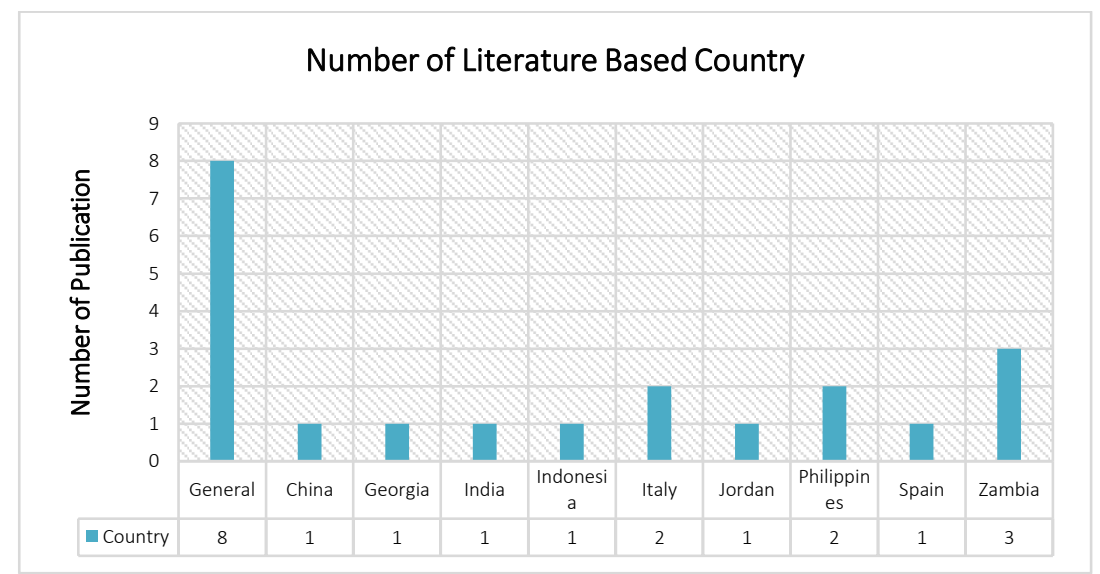

Fig. 4. Number of Literature Based Country

In Georgia, after the government implemented the rules regarding prohibiting students from going to school and changing the education system to online education, the main factor that needs attention is the facilities that support the success of online learning, especially the internet and computers or smartphones [15]. Statistically, the average internet user in Georgia is quite high. Overall, the number of houses connected to the internet was $79.3 \%$, with a distribution of $86.1 \%$ in cities and $69.9 \%$ in villages. While computer usage statistics, $62.0 \%$ of the total homes in Georgia have computers, with a distribution of $74.6 \%$ in cities and $44.7 \%$ in rural areas [31].

Based on the result of case study in one of school in Georgia by Basilaia et al. (2020), online learning is conducted by using Google Suite Education and EduPage System. The hardware used for access material course is a computer, laptop, mobile or tablet phone [15]. To provide an overview of people, process and technology for online learning implementation during COVID-19 outbreak in Georgia, we depicted it in Figure 5 below. 


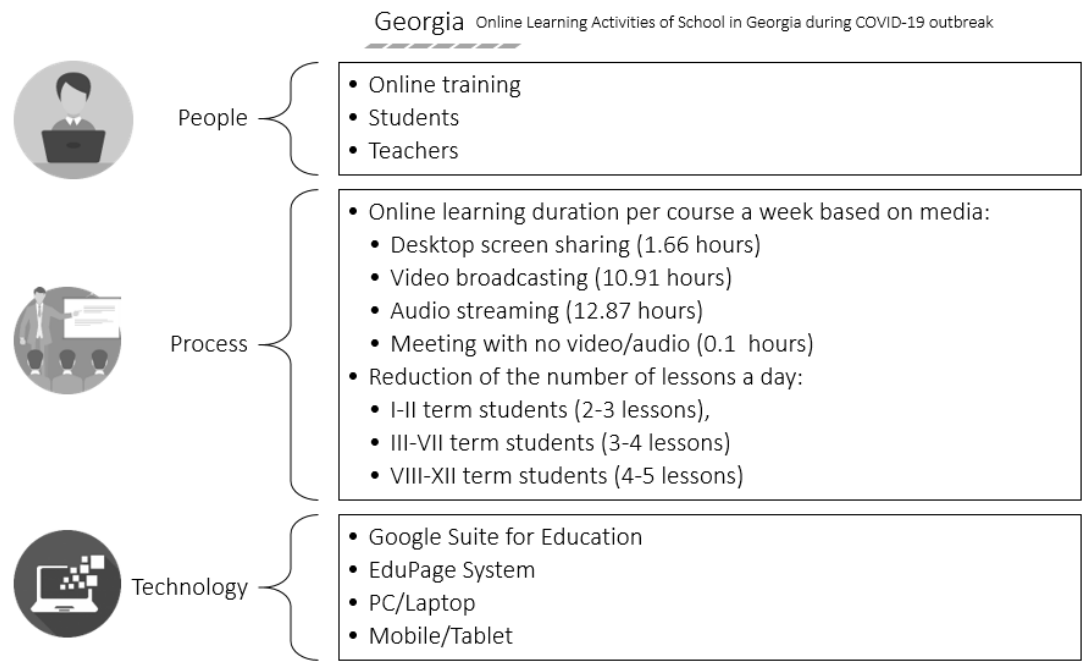

Fig. 5. Online Learning Activities of School in Georgia during COVID-19 outbreak

In India, the first positive COVID-19 patients were identified in the Kerala region in January 2020. Since June 2020, there has been a significant increase in COVID-19 cases, and there have even been as many as 43,379 COVID-19 patients who died in India. The Indian government has implemented a lockdown since March 2020. This is done to reduce the spread of COVID-19 to other regions in India. All activities in various sectors are limited so that the level of human mobility will decrease. This restriction also applies to the education sector. The government enforces rules to change the learning system into online learning [7], [32].

The implementation of lockdown regulations causes disruption of learning activities at schools and universities. This causes schools and universities to replace the learning system with online learning. Based on the result of case study in one of the universities in India by Kapasia et al. (2020), students use mobile phones to carry out online learning activities. However, students who live in remote areas and do not have adequate internet or computer facilities experience feelings of depression due to difficulties in accessing learning materials and discussing virtual classes. Percentage of learning activities: online studying $(31.5 \%)$, reading textbook with own effort $(30.6 \%)$ and both studying textbook and online $(37.9 \%)$. Moreover, the percentage of students who attended online classes: above 3 days a week (31.9\%), below 3 days a week (54.0\%) and daily (14.1\%). Technology tools that have been used to support online learning including Team Link, YouTube, Zoom App, Skype, WhatsApp, Institution/teachers website, Microsoft Kaizala, Google Meet, Google Classroom and Google Form. To present the overview of people, process and technology for online learning implementation during COVID-19 outbreak in India, it can be seen in Figure 6 below. 


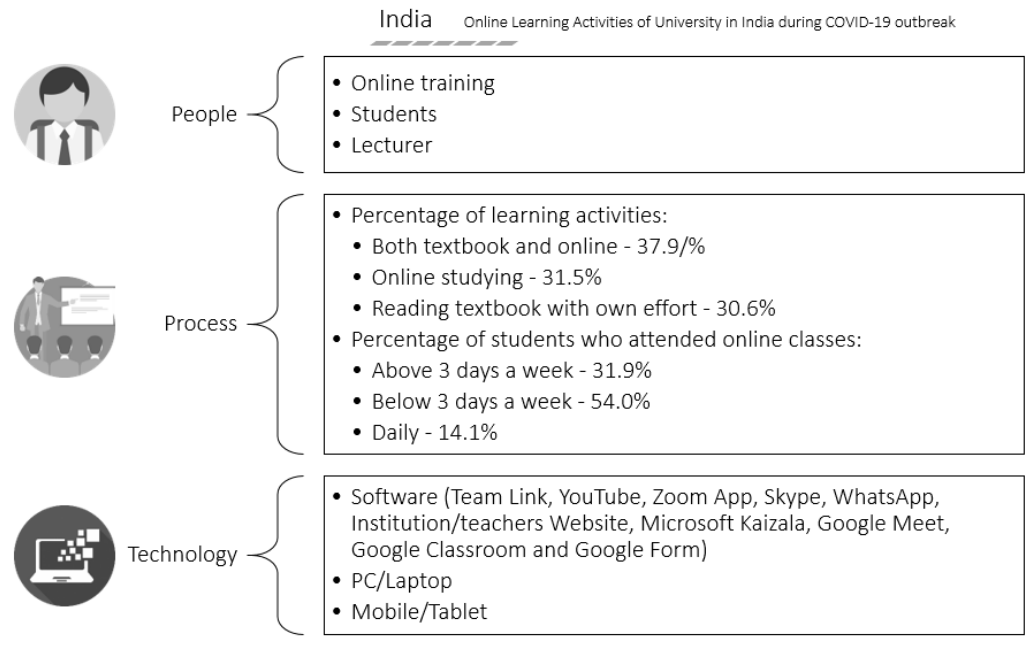

Fig. 6. Online Learning Activities of University in India during COVID-19 outbreak

To answer the research question (RQ2), "what is recommendation tools for online learning during COVID-19 outbreak?". We attempted to identify the most mentioned application in the research paper for supporting activities of online learning. The list of tools or application is mentioned and depicted in Figure 7 below.

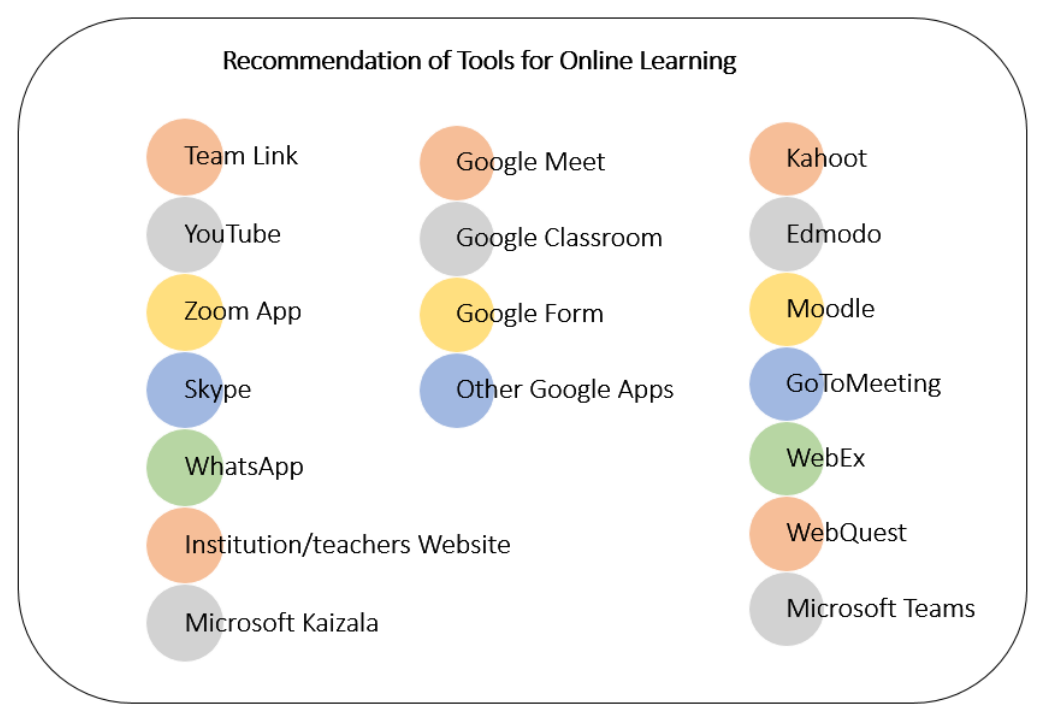

Fig. 7. Recommendation of tools for online learning 


\section{Conclusion}

This research is conducted by reviewing the related works of online learning implementation during COVID-19 outbreak. The main focus of study is on the conditions of people, the facilities and technology used, and process to support the success of online learning. The methodology of research is consisted of four phases that is adapted from PRISMA method. As the result, we found as many 21 related works that explained people, technology and process aspect to implement online learning systems successfully. The main issues of online learning during COVID-19 is availability of hardware (computer, phone, and so forth), software (Google apps, Moodle, and so on) and internet connection. We also present list of tools recommendation for supporting activities of online learning.

\section{Acknowledgement}

We would like to express special thanks of gratitude to Muhammadiyah University of Bengkulu, Universitas Mercu Buana and STIKOM Khiar Wafi that were fully supported this research.

\section{References}

[1] T. Favale, F. Soro, M. Trevisan, I. Drago, and M. Mellia, "Campus traffic and e-Learning during COVID-19 pandemic,” Comput. Networks, vol. 176, 2020. https://doi.org/10. 1016/j.comnet.2020.107290

[2] T. H. D. Nguyen and D. C. Vu, "Food delivery service during social distancing: Proactively preventing or potentially spreading COVID-19?" Disaster Med. Public Health Prep., pp. 2019-2020, 2020. https://doi.org/10.1017/dmp.2020.135

[3] Winarsih, M. Indriastuti, and K. Fuad, "Impact of Covid-19 on Digital Transformation and Sustainability in Small and Medium Enterprises (SMEs): A Conceptual Framework," in Complex, Intelligent and Software Intensive Systems, 2020, pp. 471-476. https://doi. org/10.1007/978-3-030-50454-0 48

[4] M. Chinazzi et al., "The effect of travel restrictions on the spread of the 2019 novel coronavirus (COVID-19) outbreak," Science (80-.)., vol. 368, no. 6489, pp. 395-400, 2020.

[5] T. Gonzalez et al., "Influence of COVID-19 confinement in students' performance in higher education," arXiv Prepr. arXiv2004.09545., 2020.

[6] M. Pelmin, "Readings on Coronavirus Disease (COVID-19) and the Higher Education Institution (HEIs) Emergency Preparedness in the Philippines," SSRN Electron. J., 2020. https://doi.org/10.2139/ssrn.3573896

[7] N. Kapasia et al., "Impact of lockdown on learning status of undergraduate and postgraduate students during COVID-19 pandemic in West Bengal, India," Child. Youth Serv. Rev., vol. 116, no. June, p. 105194, 2020. https://doi.org/10.1016/i.childyouth.2020.105194

[8] A. M. Connor, S. Karmokar, and C. Whittington, "From STEM to STEAM: Strategies for Enhancing Engineering \& Technology Education,” Int. J. Eng. Pedagog., vol. 5, no. 2, p. 37, 2015. https://doi.org/10.3991/ijep.v5i2.4458 
[9] R. Kandakatla, E. J. Berger, J. F. Rhoads, and J. DeBoer, "Student perspectives on the learning resources in an Active, Blended and Collaborative (ABC) pedagogical environment," Int. J. Eng. Pedagog., vol. 10, no. 2, pp. 7-31, 2020. https://doi.org/10.3991/ijep.v10i2. $\underline{11606}$

[10] P. Appiah-Kubi and E. Annan, "A review of a collaborative online international learning," Int. J. Eng. Pedagog., vol. 10, no. 1, pp. 109-124, 2020. https://doi.org/10.3991/ijep. v10i1.11678

[11] H. Noprisson et al., "Influencing factors of knowledge sharing among students in Indonesia higher educational institutions," 2016 Int. Conf. Inf. Technol. Syst. Innov. ICITSI 2016 Proc., pp. 3-8, 2017. https://doi.org/10.1109/icitsi.2016.7858214

[12] M. Sadikin, R. Yusuf, and D. Arif Rifai, "Load balancing clustering on moodle LMS to overcome performance issue of e-learning system," Telkomnika (Telecommunication Comput. Electron. Control., vol. 17, no. 1, pp. 131-138, 2019. https://doi.org/10.12928/telkomnika.v17i1.10284

[13] Ş. İ. Şalvarlı and M. D. Griffiths, "Internet Gaming Disorder and Its Associated Personality Traits: A Systematic Review Using PRISMA Guidelines," Int. J. Ment. Health Addict., 2019. https://doi.org/10.1007/s11469-019-00081-6

[14] W. Bao, "COVID -19 and online teaching in higher education: A case study of Peking University" Hum. Behav. Emerg. Technol., vol. 2, no. 2, pp. 113-115, 2020. https://doi.org/ $\underline{10.1002 / \mathrm{hbe} 2.191}$

[15] G. Basilaia and D. Kvavadze, "Transition to Online Education in Schools during a SARSCoV-2 Coronavirus (COVID-19) Pandemic in Georgia,” Pedagog. Res., vol. 5, no. 4, 2020. https://doi.org/10.29333/pr/7937

[16] Mailizar, A. Almanthari, S. Maulina, and S. Bruce, "Secondary school mathematics teachers' views on e-learning implementation barriers during the COVID-19 pandemic: The case of Indonesia," Eurasia J. Math. Sci. Technol. Educ., vol. 16, no. 7, 2020. https://doi. org/10.29333/ejmste/8240

[17] G. Gallo and M. Trompetto, "The effects of COVID-19 on academic activities and surgical education in Italy,” J. Investig. Surg., pp. 1-2, 2020.

[18] A. S. Haider and S. Al-Salman, "Dataset of Jordanian University Students' Psychological Health Impacted by Using E-learning Tools during COVID-19," Data Br., vol. 0, p. 106104, 2020. https://doi.org/10.1016/j.dib.2020.106104

[19] C. M. Toquero, "Challenges and Opportunities for Higher Education amid the COVID-19 Pandemic: The Philippine Context," Pedagog. Res., vol. 5, no. 4, p. em0063, 2020. https://doi.org/10.29333/pr/7947

[20] E. M. Mulenga and J. M. Marbán, "Is COVID-19 the Gateway for Digital Learning in Mathematics Education?” Contemp. Educ. Technol., vol. 12, no. 2, p. ep269, 2020. https:// doi.org/10.30935/cedtech/7949

[21] E. M. Mulenga and J. M. Marbán, "Prospective Teachers' Online Learning Mathematics Activities in The Age of COVID-19: A Cluster Analysis Approach," Eurasia J. Math. Sci. Technol. Educ., vol. 16, no. 9, p. em1872, 2020. https://doi.org/10.29333/ejmste/8345

[22] E. J. Sintema, "Effect of COVID-19 on the performance of grade 12 students: Implications for STEM education,” Eurasia J. Math. Sci. Technol. Educ., vol. 16, no. 7, pp. 1-6, 2020. https://doi.org/10.29333/ejmste/7893

[23] K. J. Dickinson and S. L. Gronseth, "Application of Universal Design for Learning (UDL) Principles to Surgical Education During the COVID-19 Pandemic," J. Surg. Educ., pp. 1-5, 2020. https://doi.org/10.1016/j.jsurg.2020.06.005 
[24] W. Strielkowski, "COVID-19 pandemic and the digital revolution in academia and higher education," Preprints, no. April, pp. 1-6, 2020. https://doi.org/10.20944/preprints 202004.0290.v1

[25] H. Ahmed, M. Allaf and H. Elghazaly, "COVID-19 and medical education," Lancet Infect. Dis., vol. 20, no. 7, pp. 777-778, 2020. https://doi.org/10.1016/s1473-3099(20)30226-7

[26] S. Rose, "Medical Student Education in the Time of COVID-19," JAMA - J. Am. Med. Assoc., vol. 323, no. 21, pp. 2131-2132, 2020. https://doi.org/10.1001/jama.2020.5227

[27] R. C. Chick et al., "Using Technology to Maintain the Education of Residents During the COVID-19 Pandemic," J. Surg. Educ., 2020.

[28] M. Kogan, S. E. Klein, C. P. Hannon, and M. T. Nolte, "Orthopaedic Education During the COVID-19 Pandemic,” J. Am. Acad. Orthop. Surg., vol. 28, no. 11, pp. e456-e464, 2020. https://doi.org/10.5435/jaaos-d-20-00292

[29] P. Iyer, K. Aziz, and D. M. Ojcius, "Impact of COVID-19 on dental education in the United States," J. Dent. Educ., vol. 84, no. 6, pp. 718-722, 2020. https://doi.org/10.1002/jdd.12163

[30] J. Sandars et al., "Twelve tips for rapidly migrating to online learning during the COVID19 pandemic," MedEdPublish, vol. 9, no. 1, pp. 1-14, 2020.

[31] Geostat of Georgia, "Information and Communication Technologies Usage in Households," Information and Communication Technologies Usage in Households, 2019. [Online]. Available: https://www.geostat.ge/en/modules/categories/106/information-and-communicationtechnologies-usage-in-households. [Accessed: 09-Aug-2020]. https://doi.org/10.7176/ikm/ $\underline{10-1-05}$

[32] MOHFW, "COVID-19 Statewise Status," Ministry of Health and Family Welfare - Government of India, 2020. [Online]. Available: https://www.mohfw.gov.in/

\section{Author}

Handrie Noprisson is lecturer of Computer Science in Universitas Mercu Buana, Indonesia. His research interests are Data Science and Information System. He can be contacted at e-mail address: handrie.noprisson@mercubuana.ac.id

Article submitted 2020-08-20. Resubmitted 2020-09-24. Final acceptance 2020-09-24. Final version published as submitted by the authors. 